\title{
International Production in Developing Economies, Changes in Key Factors for Management
}

\author{
H.J. Steenhuis ${ }^{1}$, E.J. de Bruijn ${ }^{2}$ \\ ${ }^{1}$ Department of Management, College of Business and Public Administration, \\ Eastern Washington University, Spokane, USA \\ ${ }^{2}$ Technology and Development Group, School of Business, Public Administration and Technology, \\ University of Twente, Enschede, The Netherlands
}

\begin{abstract}
Many manufacturing companies have become involved in international production. The primary reasons for moving manufacturing offshore are access to low labor cost, access to markets and/or access to skilled labor. However, many companies fail when operating in international markets. Historically Western companies have been faced with challenges when operating in international situations, in some instances leading to huge losses. This indicates that operating in international markets, and in particular in developing countries, is a challenging task. Few models exist that can aid the management of overseas, in particular developing countries', operations. In this paper, based upon ongoing research since 1971, we present a model that is aimed at helping managers in these situations. The model distinguishes factors that can be different in international markets, and combines these with their effect on different manufacturing cost categories. The model facilitates managers in their assessment of international cost differences and, eventually, with preventing costly mistakes.
\end{abstract}

Keywords - International operations, cost analysis, developing countries

\section{INTRODUCTION}

Many manufacturing companies have become involved in international production. The primary reasons for moving manufacturing offshore are access to low labor cost, access to markets and/or access to skilled labor. However, many companies fail when operating in international markets. Historically Western companies have been faced with challenges when operating in international situations. For example Beijing Jeep in China [1] and Cummins Engine in India [2] show the difficulties of operating in environments that are very different from those in developed nations. Problems also occur in more similar environments. For example Bank of America entered Japan but subsequently had to scale down its operations [3]. Another example is McDonalds, which faced difficulties in Japan [4]. In some instances the costs of failure have become publicly available leading to astonishing figures. During the 1980s and 1990s Renault from France is estimated to have lost $\$ 750$ million in its USA adventure and Imperial Tobacco (British) lost over $\$ 300$ million with its acquisition and subsequent sale 5 years later of Howard Johnson (USA) [5]. Recently $\mathrm{MMO}_{2}$, a UK company, sold its Dutch arm for \$25 million. Since its acquisition in 1996 it had invested approximately $\$ 2.2$ billion [6]. Another example is Numico, a Dutch company, which bought Rexall, a USbased company in 2000 for $\$ 1.8$ billion and subsequently sold it in 2003 for $\$ 250$ million [7]. Finally, in 1999 US based Reliant bought Una, a Dutch company, for \$2.4 billion. It was sold in 2003 for $\$ 1.3$ billion [8].

All of these examples show that operating in international markets, and in particular in developing countries, is a challenging task. Of course business schools have been aware of the challenges and many courses are currently taught in business schools dealing with issues in international management. However, a quick few at international management textbooks reveals that these books are primarily economics or macro oriented and mainly emphasize macro level differences between developed countries. They do not deal with the details on how organizations should actually manage their international production sites and operations nor do they provide enough insight into the particular differences with regard to developing countries. Few models exist that can aid the management of overseas, in particular developing countries', operations. In this paper, based upon our ongoing research since 1971, see e.g. [9-11], we present a model that is aimed at helping managers in these situations.

\section{INTERNATIONAL FAILURES}

Ferdows [12] mentions three strategic reasons for companies to operate in international markets: access to low-cost production, access to skills and knowledge, and proximity to market. Steenhuis and de Bruijn [13] added a fourth motive: political pressure. To determine whether companies are failing in their international operations, their results should be compared with the strategic reason for moving into international markets. For example, if a company starts international operations to be closer to an international market, then the number of sales in that foreign market is an indicator of success or failure. In this particular instance disappointing sales may be caused by a wrong market assessment. For example, companies may have looked at the number of people in a particular country without paying attention to income levels, income distribution or purchase power.

In this paper the focus will be on evaluating access to low-cost production as a strategic reason for international operations. Nowadays, many companies move operations from domestic to international locations to benefit from low-labor cost advantages that especially developing countries offer. Examples occur in manufacturing as well as in service industries, e.g. calling centers. However, operating in international environments is often more 
complicated than initially expected and as a result operating cost in a developing country may be higher than in a developed country.

\section{INTERNATIONAL OPERATIONS COST}

Based on the available literature and our own previous empirical research, we will develop a schema to provide managers with a tool to accurately assess the differences between operating in international environments versus domestic environments. In particular, we will emphasize the consequences of developing countries' environments on cost structures. For example total production cost calculation comparisons for a metal test piece for four Indonesian companies and a Dutch company led to the results in table I. This indicates that low-labor cost countries do not always offer lower total cost of production [14].

Table I

Comparison of costs for a test piece

\begin{tabular}{|l|c|c|c|c|}
\hline Factory & $\begin{array}{c}\text { Manuf. } \\
\text { time }\end{array}$ & $\begin{array}{c}\text { Manuf. } \\
\text { cost }\end{array}$ & $\begin{array}{c}\text { Raw } \\
\text { material }\end{array}$ & $\begin{array}{c}\text { Total } \\
\text { production }\end{array}$ \\
\hline Indon. 1 & $19.30 \mathrm{~h}$ & $\$ 43.50$ & $\$ 63.75$ & $\$ 107.25$ \\
\hline Indon. 2 & $10.34 \mathrm{~h}$. & $\$ 20.72$ & $\$ 63.75$ & $\$ 84.47$ \\
\hline Indon. 3 & $6.53 \mathrm{~h}$. & $\$ 21.84$ & $\$ 63.75$ & $\$ 85.59$ \\
\hline Indon. 4 & $16.85 \mathrm{~h}$. & $\$ 32.56$ & $\$ 64.25$ & $\$ 96.81$ \\
\hline Dutch 1 & $2.30 \mathrm{~h}$. & $\$ 36.60$ & $\$ 22.50$ & $\$ 59.10$ \\
\hline
\end{tabular}

The total cost of a company's operations can be expressed as fixed versus variable cost and direct versus indirect cost. This leads to four cost categories, see table II, which includes examples for each category [15].

TABLE II

COST CATEGORIES

\begin{tabular}{|c|l|l|}
\hline Cost & \multicolumn{1}{|c|}{ Direct } & \multicolumn{1}{c|}{ Indirect } \\
\hline Fixed & $\begin{array}{l}\text { Tires used in assembly of } \\
\text { an automobile where the } \\
\text { cost object is each } \\
\text { individual automobile } \\
\text { assembled }\end{array}$ & $\begin{array}{l}\text { Power costs where power } \\
\text { is metered only to the } \\
\text { assembly department and } \\
\text { the cost object is each } \\
\text { individual automobile } \\
\text { assembled }\end{array}$ \\
\hline Variable & $\begin{array}{l}\text { Marketing department's } \\
\text { supervisor's salary where } \\
\text { the cost object is the } \\
\text { marketing department }\end{array}$ & $\begin{array}{l}\text { Board of directors' fees } \\
\text { where the cost object is } \\
\text { the marketing department }\end{array}$ \\
\hline
\end{tabular}

How the actual costs of operations are allocated to these four categories depends on the organization, i.e. the cost accounting methods and standards used. An important issue for international operations is whether all of the costs of international operations are allocated to the international operation or whether some of these costs are actually allocated to another office. For example Hayashi [16] provided examples where companies allocate the costs of foreign expatriates to a domestic head office rather than the international operation. This, of course, affects the perceived total cost of international operations and the (cost) evaluation of these operations. Another important issue is how well the company can distinguish between direct and indirect costs. This refers in particular to the category of indirect manufacturing cost or overhead, i.e. all manufacturing costs that cannot be identified specifically with or traced to the cost object in an economically feasible way. Companies in developing countries may not be knowledgeable about sophisticated accounting tools to distinguish direct from indirect costs. This can in particular occur in centralized environments and it affects overhead rates. For example, in Romania, we found overhead rates of $80 \%-90 \%$ [17] whereas in most manufacturing companies, overhead rates are between $25 \%$ and $50 \%$ of total costs [18]. Companies that outsource to these environments may underestimate these overhead rates and may also find them unrealistic. In a search for low cost operations, many companies look for low-labor cost environments. However, as Dornier et al. [19] point out; "In many cases, manufacturing managers overstate the importance of direct labor cost because it is the easiest to quantify and the most readily apparent cost element. For many years, standard accounting practices seriously inflated the importance of direct labor costs. Overhead cost allocations were typically based on direct labor costs, thus prompting companies to allocate a large percentage of fixed costs, many of them unaffected by the location decision, to products with slightly higher direct labor cost components. This form of overhead cost allocation cast offshore sourcing as the panacea for reducing overhead expenses, particularly for companies in mature or declining markets. After pursuing such offshore sourcing, many companies were unpleasantly surprised to find that offshore sourcing can lead to fragmented production processes, fewer but less productive facilities, and, in many cases, higher total overhead. Recent advances in technology and production methods have reduced direct labor cost to less than $15 \%$ of total production costs for most manufacturing industries. In high technology industries it is often less than 5\%. These facts make an offshore sourcing strategy obsolete in many cases. It is irrational to allow the cost category that represents the smallest percentage in overall product costs to drive the location of operations activities."

\section{DEVELOPING COUNTRY ENVIRONMENT}

Austin [20] provides an overview of factors in developing countries, which influences businesses differently compared to developed countries. Austin's Environmental Analysis Framework combines two views to analyze the environment. First, he distinguished four categories of environmental factors: economic, political, cultural and demographic. Second, he distinguishes four environmental levels: the international level, the national level (in particular a government's strategies and policies), the industry level, and the company level (functional areas). Each of the four levels of environment is shaped by the four environmental factors. 
TABLE III

ENVIRONMENTAL FACTORS

\begin{tabular}{|l|l|l|l|}
\hline Economic & Political & Cultural & Demographic \\
\hline - natural & -stability & - social & - population \\
resources & -ideology & structure and & growth \\
- labor & -institutions & dynamics & - age structure \\
- capital & -geopolitical & - human & - urbanization \\
- infrastructure & links & nature & - migration \\
- technology & & perspective & - health status \\
& & - time and & \\
& & space & \\
& & orientation & \\
& & -religion & \\
& & -gender roles & \\
& & -language & \\
\hline
\end{tabular}

\section{LINKING ENVIRONMENT WITH COST}

In the following discussion, three commonly used cost categories for manufacturing companies are used: direct labor costs, direct materials costs and indirect manufacturing costs (or overhead) [21]. Indirect variable costs and indirect fixed costs are therefore combined.

\section{A. Direct labor costs}

Direct labor cost is, in addition to the labor cost per hour, determined by labor productivity, i.e. the number of hours required to complete a task. This is primarily affected by six factors:

1. labor (skill level); the skill level and level of experience affects the productivity level of employees.

2. infrastructure (physical); many developing countries have poor physical infrastructure, e.g. roads. This can indirectly affect productivity of employees as goods may take longer to transport and may not be available to use in production.

3. infrastructure (information availability); many developing countries do not offer the same information services as are offered in developed countries. Therefore, to find certain types of information, for example to solve technical problems, takes longer than in developed countries.

4. technology (technological level); typically developing countries possess less advanced technologies than the developed countries. If less advanced production technologies are used, then typically more labor is required to get the job done (although this may be cheaper than more advanced technology with less labor).

5. time and space orientation; different cultures have different attitudes towards time. The "time is money" attitude from for example the USA is not always found in other countries. A more leisure approach towards work affects the productivity of employees.

6. religion; the religious affiliation affects the number of paid holidays and/or time allowed within companies to carry out religious activities, e.g. in India many companies allocate space and time for employees to carry out Hindu practices at the shopfloor.

\section{B. Direct materials costs}

Direct materials costs are primarily affected by three factors.

1. natural resources (availability); in many instances, developing countries do not possess the required quality of material. This is linked with the technology that is used in production. It may be possible to improve the quality but this creates additional costs.

2. infrastructure (physical); poor physical infrastructure influences transportation time which affects the cost of materials purchased from outside sources.

3. technology (level); typically developing countries have industries that are not as sophisticated as those in developed countries. One of the consequences is that the number of products that are produced is generally smaller than in developed countries and consequently the cost for parts and equipment can be higher than in developed nations due to a lack of scale economies.

\section{Indirect manufacturing costs or overhead}

The above direct cost categories occur in both developed and developing countries and the treatment above has focused on describing the differences in the amount of money for these categories. Besides these cost categories there are often additional costs for operating in international environments. For companies that have no experience in operating in developing countries, some of these costs may be unexpected. These costs are typically allocated to overhead or to a domestic head office, thereby distorting the real cost of international operations.

For the indirect manufacturing costs or overhead, a distinction can be made between recurring costs and nonrecurring costs. For example, if a company sets up an international subsidiary for the production of a particular product then it is faced with costs which only appear once, e.g. the initial cost of negotiating, this is termed non-recurring. The costs that are recurring are for example costs for secretaries.

Recurring costs are:

- 'government' cost; in many developing countries, the government plays a major role. This may lead to additional costs. For example, in Romania, the construction of a factory had to be started over after a visit from the Romanian president who wasn't satisfied with its appearance [22]. Another example is Hua Fei (a Philips joint venture in Nanjing). The design drawings for the factory had to be approved by the government. They concluded that the floors were constructed too lightly and to comply with regulations the floors were increased in thickness. However, due to the increase in thickness, the large machines didn't fit between floor and ceiling anymore. Eventually it was decided to built the machines partly into the floors. These examples show increased cost as a result of government 
intervention which can be considered political instability.

- 'corruption' cost; most developing countries have legal sanctions against bribes, but these are often not consistently enforced. As a result, companies are faced with extra costs. Either, as the undesirable result of paying bribes. Or, alternatively, if bribes are not paid, companies face extra costs due to undesirable treatments. For example, parts and/or materials may be stuck at customs for an undetermined time, causing production delays. This cost factor relates to political ideology.

- Rework cost; these are a result of problems with the quality of the work. Even if employees are skilled quality problems may still occur. The issue is one of consistency, which can be linked to cultural characteristics. For example in one company, employees were initially highly motivated and achieved high quality products. However, after they 'proved' themselves, the employees lost interest in the project and this resulted in more 'sloppy' work.

Non-recurring cost are:

- Construction costs; if a new factory has to be built, or an existing factory needs to be modernized, there are costs associated with the construction. This is not separately discussed by Austin [20] but will be considered as an economic factor. The construction costs will be affected by the available natural resources (affects price of materials), skill level of employees (affects productivity) and level of infrastructure (affects transportation costs of building materials).

- Training costs; local employees, due to their skill level may need to be trained. This can occur at the company's home location (requires travel arrangements) or in the host country.

- Expatriate cost; in many instances, especially at the beginning of operating in international markets, there is a need for foreign expatriates to provide technical or managerial assistance. These expatriates may have to stay overseas for multiple years, typically with their family. The cost, including the regular salary, of an expatriate can easily reach $\$ 250,000$ per year. Behrman and Wallender [23] provide an example of Ford's establishment of a plant in South Africa which included several man-years of expatriates from a range of fields such as industrial engineers, service managers, quality control and purchasing agents. Another example is setting up an aircraft production line in Romania which, in addition to local training hours, included roughly 40,000 man-days of technical assistance [24].

- Translation costs; when production is moved to another location, it may become necessary to get production documents, e.g. process sheets, planning sheets etc., translated. This aspect is not specifically mentioned by Austin but will be regarded as technology learning costs.

- Communication costs; when a new factory is set up, or when technology is outsourced to a new supplier in a developing country, this new supplier has to learn the new technology. This is part of the training costs. However, in addition to these costs, there may be a number of technical questions. For example, the design information from the home company may not be completely accurate [25]. To solve this issue requires communication between the two companies. This may, besides the cost associated with the communication, affect production if solutions take extra time and/or if time zone differences exist. This factor is not mentioned by Austin [20] but it will be considered part of the economic factors (technology)

- Negotiating cost; whereas for example in the USA it is possible to reach a deal rather quickly, in some other countries this is not the case. For example in China it takes many sessions to reach a deal [26]. This results in cost due to time delays, cost for the employee time associated with negotiations, and travel cost (hotel, plane ticket etc.). This is affected by cultural factors (human nature and time \& space) and political (ideology, amount of government involvement)

- Different learning curves; the learning curve may, depending on the type of production, play an important role. Companies should note that learning curves in international settings may be different from those in domestic settings. These differences can not be attributed to one particular environmental factor but rather, are caused by the environment as a whole. A higher learning curve will result in slower productivity improvements and thus added costs.

The above given explanations lead to the following linkages between the three cost categories and environmental factors:

\begin{tabular}{|l|l|}
\hline Economic & \\
- Labor (skill level) & \\
- Infrastructure (physical) & \\
- Infrastructure \\
(information) \\
- Technology (level)
\end{tabular}

Fig. 1. Environmental effects on direct labor cost

\begin{tabular}{|c|c|}
\hline $\begin{array}{l}\text { Economic } \\
\text { - Natural resources } \\
\text { (availability) } \\
\text { - Infrastructure (physical) } \\
\text { - Technology (level) D }\end{array}$ & $\begin{array}{c}\text { Political } \\
\bullet\end{array}$ \\
\hline Cultural & Demographic \\
\hline
\end{tabular}

Fig. 2. Environmental effects on direct material costs 


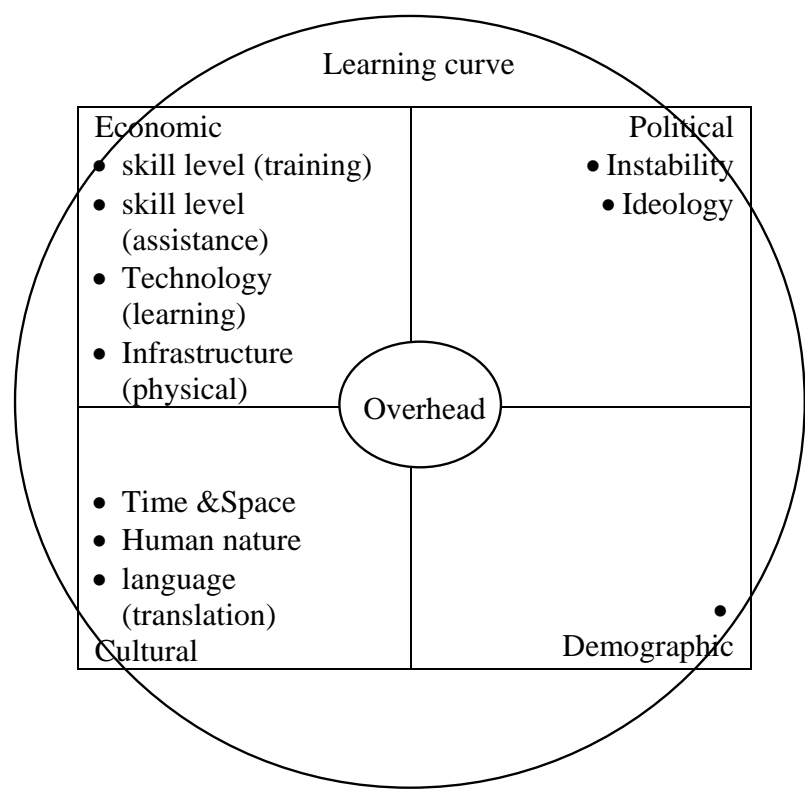

Fig. 3. Environmental effects on overhead

\section{CONCLUSION}

There are different strategic motives for companies to operate in international environments. One of the motives is to get access to low-cost production. In this instance companies often relocate production to low-labor cost countries, i.e. typically developing countries. However, they do not always succeed in lowering their total production cost. In this paper, based on the current literature and our own empirical research, we have described how differences in the international environment can impact the cost and cost structures of companies. In particular, economic and cultural factors affect the direct labor costs. Economic factors also affect direct material costs. Economic, cultural and political factors affect overhead. Several of these factors occur in especially in developing countries and are often underestimated by companies from developed countries when they move production to developing countries.

\section{REFERENCES}

[1] J. Mann, Beijing Jeep, The short, unhappy romance of American business in China, New York: Touchstone, 1989.

[2] J. Baranson, Manufacturing problems in India, The Cummins Diesel experience, Syracuse: Syracuse University Press, 1967.

[3] D. Ibison and B. Jopson, "Bank of America downsizes Japanese Operations," Financial Times, February 14, 2003, pp. 17.

[4] B. Rahman and M. Sanchanta, "McDonald's loss in Japan raises questions," Financial Times, February 15-16, 2003, pp. 8.

[5] J. Willman, "In European countries, there are three of four competitors. In the US, there are 10 or 20," Financial Times, February 25, 2003, pp. 11.

[6] R. Budden, " $\mathrm{MMO}_{2}$ sells Dutch arm for $25 \mathrm{~m}$," Financial Times, April 15, 2003, pp. 24.
[7] I. Bickerton, "Dutch healthfood group sells Rexall Sundown for \$250m," Financial Times, June 11, 2003, pp. 15.

[8] S. McNulty and I. Bickerton, "Reliant takes $\$ 900 \mathrm{~m}$ loss on sale to Nuon," Financial Times, February 21, 2003, pp. 18.

[9] E.J. de Bruijn, "Systematic strategy determination for industrial development", in Management Sciences and the development of the Asian economies, S.J. Torok, Ed. Singapore: Times Book International, 1979.

[10] E. J. de Bruijn and X. Jia, "Transferring technologies to China by means of joint ventures," Research Technology Management, Vol.36, no.1, 1993, pp. 17-22.

[11] E.J. de Bruijn and J. E. Coetzee, "Corporate restructuring for operational competitiveness," in Strategic issues at the dawn of a new Millennium, M.S.S. El-Namaki, R.Samson Eds., Leiderdorp, Netherlands: Lansa publishing, 1999, pp 273390.

[12] K. Ferdows, "Making the most of foreign factories," Harvard Business Review, vol. 6, no. 2, March-April 1997, pp. 73-88.

[13] H.J. Steenhuis and E.J. de Bruijn, "Are international shifts in production location a reality? Evidence from passenger car production in several countries," in Exploiting the potential of international supply networks, Proc. $8^{\text {th }}$ Annual Cambridge International Manufacturing Symposium, Cambridge, UK, pp. 58-66.

[14] R. van Hasselt, E.J. de Bruijn and S.H. Wirjomartono, "An investigation into the appropriate application of modern methods of production and management in the engineering industry of Indonesia", Annals of the CIRP, vol. 25, no. 1, 1977, pp. $263-268$

[15] C.T. Horngren and G. Foster, Cost accounting, A managerial emphasis, $7^{\text {th }}$ edition, London, UK: Prentice Hall International, p. 31.

[16] N. Hayashi, "Essence and evolution of the Toyota production system," presented at the $2^{\text {nd }}$ World Conference, $15^{\text {th }}$ Annual POMS conference,, Cancun, Mexico, April 30 - May 3, 2004.

[17] H.J. Steenhuis, "Manufacturing West European aircraft parts in East Europe, A case study on the transfer of unstable production technology under a supply contract", Working Paper No. 98 (Interview 34), Technology and Development Group, University of Twente, The Netherlands, 1999.

[18] T. Hill, Manufacturing strategy, Third edition, Boston: Irwin McGraw-Hill, 2000, p. 288.

[19] P.P. Dornier, R. Ernst, M. Fender and P. Kouvelis, Global Operations and Logistics, Hoboken, NJ: John Wiley \& Sons, 1998, p. 83.

[20] J.E. Austin, Managing in developing countries, Strategic analysis and operating techniques, New York: The Free Press, 1990.

[21] C.T. Horngren and G. Foster, Cost accounting, A managerial emphasis, $7^{\text {th }}$ edition, London, UK: Prentice Hall International, p. 35.

[22] H.J. Steenhuis, "International technology transfer, Building theory from a multiple case-study in the aircraft industry", Ph.D. dissertation, University of Twente, Enschede, The Netherlands, 2000

[23] J.N. Behrman and H.W. Wallender, Transfers of manufacturing technology within multinational enterprises, Cambridge, MA: Ballinger Publishing Company, 1976.

[24] H.J. Steenhuis, "Manufacturing aircraft in East Europe to a West European standard, A case study on the transfer of technology under a production license", Working Paper No. 96, Technology and Development Group, University of Twente, The Netherlands, 1999.

[25] H.J. Steenhuis and E.J. de Bruijn, "Exploring knowledge transfer within manufacturing networks and codified information characteristics: the hidden dangers of inaccurate information", International Journal of Technology Transfer and Commercialization, in press.

[26] X. Jia, "Creating Sino-foreign equity joint ventures, Technology transfer: negotiation, product selection and localization", Ph.D. dissertation, University of Twente, Enschede, The Netherlands, 1993. 